\title{
Prevalence of parasitism in the Grotto Sculpin (Cottus specus), a new species of cave-adapted fish from southeastern Missouri, USA
}

\author{
Julie L. Day ${ }^{1,3}$, David E. Starkey ${ }^{1,4}$, Joseph E. Gerken², \\ I Department of Biology, University of Central Arkansas, Conway, AR, USA 2 Kansas Cooperative Fish and \\ Wildlife Research Unit, Kansas State University, Manhattan, KS, USA 3 Leibniz Centre for Tropical Marine \\ Ecology (ZMT), Fahrenheitstraße 6, 28359 Bremen, Germany 4 Department of Natural Sciences, College of \\ Coastal Georgia, Brunswick, GA, USA
}

Corresponding author: Julie L. Day (Julie.lynne.day@gmail.com)

Academic editor: O. Moldovan | Received 26 October 2013 | Accepted 30 December 2013 | Published 8 January 2014

Citation: Day JL, Starkey DE, Gerken JE (2013) Prevalence of parasitism in the Grotto Sculpin (Cottus specus), a new species of cave-adapted fish from southeastern Missouri, USA. Subterranean Biology 12: 3-14. doi: 10.3897/ subtbiol.12.6503

\begin{abstract}
Acanthocephalan parasites infecting the newly described Grotto Sculpin (Cottus specus), a state-threatened and federally endangered troglomorphic fish endemic to Perry County, Missouri, were identified in fish from six cave and four non-cave karst streams. Infection rate and infestation severity were higher among fish from cave streams as compared to non-cave streams. Fish from several caves presented with cases of severe infection and near complete parasite occupation of the intestinal tract. Increased cannibalism and variable water quality are proposed as possible explanations for increased Grotto Sculpin parasitism. This observation suggests that the health of cave fauna may be tied to diet and host population dynamics, and that species subject to severe dietary restrictions and the effects of anthropogenic disturbances may have high vulnerability and conservation risks.
\end{abstract}

\section{Keywords}

Sculpin, cave, parasite, ecology, acanthocephalan

Copyright Julie L. Day et al. This is an open access article distributed under the terms of the Creative Commons Attribution International License (CC BY 4.0), which permits unrestricted use, distribution, and reproduction in any medium, provided the original author and source are credited. 


\section{Introduction}

Comparative studies of host-parasite relationships have shown tremendous potential for illuminating the underlying mechanisms of speciation, dispersal, gene flow, effective population size, and both evolutionary and ecological patterns of occurrence that might otherwise remain obscure (Biek et al. 2006, Blakeslee et al. 2008, McCoy et al. 2005, Nieberding et al. 2005, Whiteman and Parker 2005, Whiteman et al. 2007, Wirth et al. 2005). Their emerging use in untangling ecosystem dynamics and answering questions pertaining to host ecology, coupled with recent increases in research on cave systems and their fauna draw cause for concern to the paucity of empirical investigations. Literature reviews have revealed limited data regarding parasites of cave fish species, with reports primarily confined to bat ectoparasites (Kurta et al. 2007, Poissant and Broders 2008), and incidences reported in select specimens or species of cavefishes, salamanders, and beetles (Fenolio et al. 2013, Hendrickson et al. 2001, McAllister et al. 2006, Santamaria and Faille 2007, Niemiller and Poulson 2010, McAllister et al. 2013). The largely unreported role of parasites in cave ecosystems limits the application of practical aquatic ecology conceptions and the validity of connectivity studies that do not account for parasitism and energy transfer in these harsh and highly specialized environments.

In cave systems, food scarcity is often cited as a key ecological factor with respect to persistence and resilience for many populations (Eigenmann 1909, Poulson 1963 , Poulson and Lavoie 2000, Trajano 2001, Culver and Pipan 2009). It is estimated that only $0.001 \%$ of the energy available to surface systems is available to subterranean habitats (Aley and Aley 1979). Such a restricted direct energy supply forces many cave taxa to rely more heavily on energetic input from the surface through indirect means such as plant debris, detritus, dissolved organics (Ginet and Decou 1977, Langecker 2000, Venarsky et al. 2012), and cannibalism. Many animals living in subterranean habitats are opportunistic feeders that consume a wide variety of prey items and with inconsistent regularity due to stochastic conditions underground (Trajano 2001).

With such variable ecosystem dynamics, the success of parasites of cave fauna is largely dependent on ecology of both the host and parasite. Definitive host specialization, paratenic host requirements, and host biogeography can all affect parasite survival (Seneviratne et al. 2009). Host allopatry, or isolation, may limit transmissibility of parasites between hosts, therefore restricting dispersal potential and successful colonization of primary host populations (Dick and Patterson 2007). In conjunction with the already limited diversity of cave taxa available for parasite utilization, opportunities to colonize additional or alternative hosts are much narrower than in more specious systems. Similarly, potential paratenic host species for parasites with oligoxenous life cycles may also be reduced, further limiting the diversity and likelihood of successful colonization of cave taxa.

Grotto Sculpin (Cottus specus) have recently been distinguished from the Banded Sculpin species complex (Cottus carolinae) and are endemic to cave systems underlying Perry County, Missouri (Adams et al. 2013, Day et al. in press). These uniquely cave- 
adapted fish are state-threatened and listed as endangered in the United States under the Endangered Species Act (USFWS 2013). Preliminary investigations of Grotto Sculpin parasite diversity uncovered an elevated occurrence of acanthocephalans in cave-dwelling fish populations as compared to surface-dwelling Banded Sculpin (Day and Gerken, unpublished data). Acanthocephalan worms are primarily intestinal parasites that employ a spiny proboscis for attachment to their fish, bird, or mammalian hosts (Kennedy 2006). When found in high concentrations, as they often are in other cottids (Muzzall and Bowen 2002), acanthocephalans have been shown to negatively affect the condition of their host (Kennedy 2006). Infection rates by these worms vary in conjunction with water quality parameters, and may therefore serve as biomarkers or indicators of the degree of environmental stress fish are facing and can be used as an index of overall fish health (Galli et al. 2001, Kahn 2004).

In this study, we provide one of the first dedicated investigations of cavefish parasite ecology and explore the efficacy of parasites for comparing habitat-specific infection rates as indicators of the prevalence of fish parasites in cave ecosystems. In Grotto Sculpin, we sought to identify potential at-risk populations and those most susceptible to environmental perturbations from surface ecosystems by comparing relative parasite loads between cave and surface populations of $C$. specus. We hypothesized that decreased parasite loads would be present in cave populations due to limited food web exploitation and resulting difficulties in locating appropriate paratenic hosts.

\section{Methods}

\section{Study sites}

Perry County lies on the Salem Plateau in the northeast Ozark Highlands of southeastern Missouri, USA (Figure 1) and contains 656 known caves, including the states' four longest (Lamping and Laws 2005). This dense karst region contains one of the highest concentrations of caves in the United States, with terrain typified by sinkholes, caves, sinking streams, and springs representative of a sinkhole plain. Predominantly limestone formations, these caves are thought to have formed during the Pleistocene era (Vandike 1985). Detailed recharge delineation data for Perry County caves can be found in Moss 2013. In this unique landscape, subterranean streams outnumber surface streams, driving water drainage underground and increasing the potential for both aquatic organisms and organic matter to enter subterranean systems. Because of the porous nature of the landscape, large amounts of sedimentation and anthropogenic contaminants are carried directly into the karst systems which is likely to impact fish condition and population size (Burr et al. 2001, Fox et al. 2010). Sampling for this study took place in six caves inhabited by Grotto Sculpin, one resurgence stream, and three surface streams (Table 1). These locations were selected as study locations because of their accessibility and relatively consistent, population abundances of Grotto Scul- 


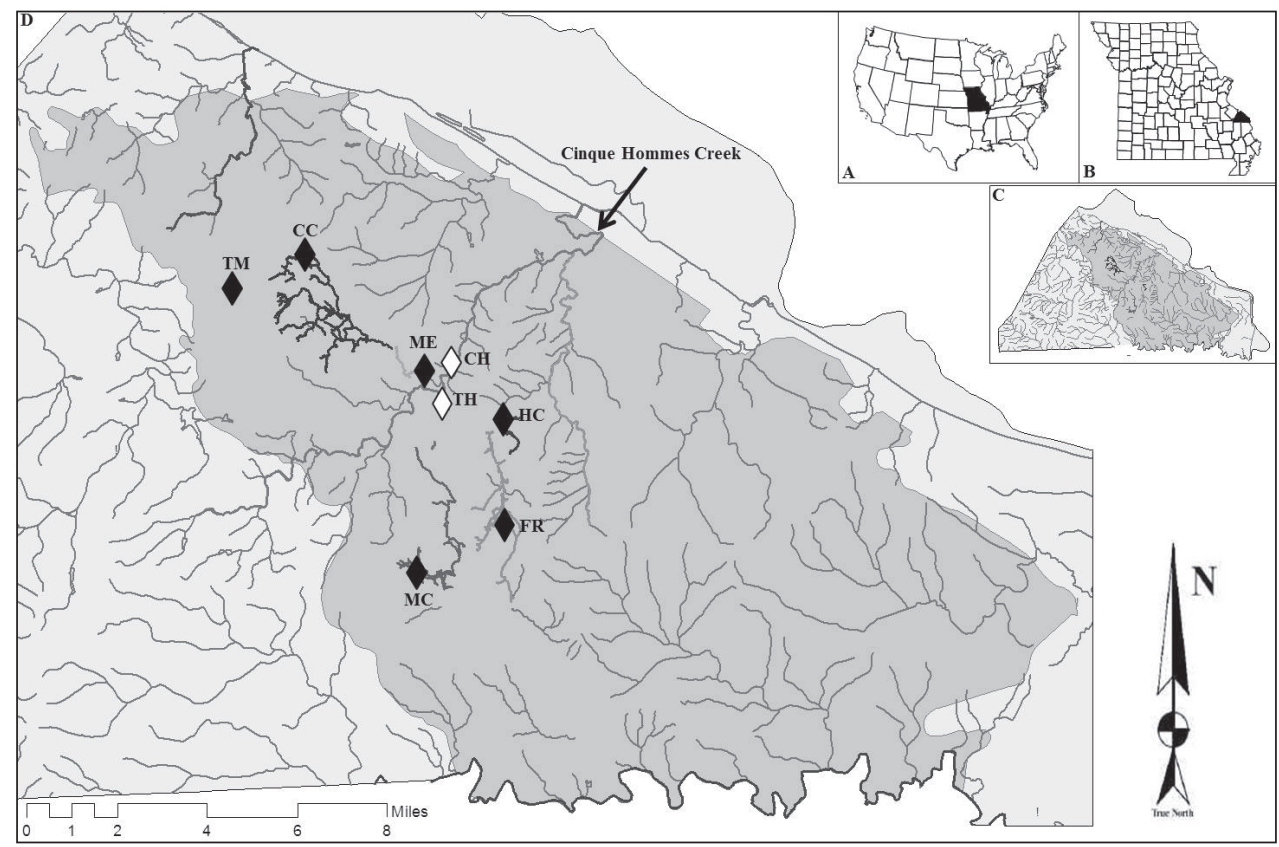

Figure I. Panes A-C provide geographic reference within the interior United States. Pane D shows the geographic distribution of grotto sculpin cave systems in Perry County, Missouri and denotes sampling localities in black for caves and white for non-cave streams. Shaded area denotes karst sinkhole plain boundaries, and bolded streams indicate subterranean cave streams. See Table 1 for location abbreviations.

Table I. Parasitism by L. thecatus in Grotto Sculpin from non-cave and cave streams in Perry County, Missouri.

\begin{tabular}{c|c|c|c|c|c|c|c|c}
\hline Site & Abr. & Habitat & N & N Parasitized & N Worms & Prevalence & Intensity & Abundance \\
\hline Big Creek & BC & Surface & 29 & 0 & 0 & $0 \%$ & 0 & 0 \\
\hline Collier Spring & CS & Surface & 10 & 5 & 7 & $50 \%$ & 1 & 1 \\
\hline Cinque Hommes & CH & Surface & 29 & 6 & 10 & $21 \%$ & 2 & 0 \\
\hline Thunderhole & TH & Resurg & 18 & 9 & 49 & $50 \%$ & 5 & 3 \\
\hline Mertz Cave & ME & Cave & 16 & 9 & 24 & $56 \%$ & 3 & 2 \\
\hline Tom Moore Cave & TM & Cave & 32 & 21 & 89 & $66 \%$ & 4 & 3 \\
\hline Mystery Cave & MC & Cave & 46 & 33 & 995 & $72 \%$ & 30 & 22 \\
\hline Hot Caverns & HC & Cave & 4 & 3 & 115 & $75 \%$ & 38 & 29 \\
\hline Crevice Cave & CC & Cave & 11 & 10 & 73 & $91 \%$ & 7 & 7 \\
\hline Flaming River & FR & Cave & 34 & 31 & 266 & $91 \%$ & 9 & 8 \\
\hline & & Total & $\mathbf{2 2 9}$ & $\mathbf{1 2 7}$ & $\mathbf{1 6 2 8}$ & $\mathbf{5 5 \%}$ & $\mathbf{1 3}$ & $\mathbf{7}$ \\
\hline
\end{tabular}

pin (Day et al. 2009). Sampling karst streams is notoriously treacherous due to difficulty of cave penetration, stochastic high water events, point and non-point pollution events, and cave air quality. Every effort was made to sample as exhaustively as possible within a cautious margin of safety. 


\section{Sampling}

Two-hundred and twenty-nine Grotto Sculpin were collected using straight line seines $1.8-3.1 \mathrm{~m}$ by $1.2 \mathrm{~m}$ (3 mm mesh) from selected sampling localities in Perry County, Missouri. Sampling trips were conducted between February 2007 and October 2008. Exhaustive seine hauls were made at two riffle locations per site, and whole specimens were sacrificed in the field by MS-222 overdose. Fish were either preserved in 70\% ethanol in the field or frozen whole at $-30^{\circ}$ in the laboratory. To minimize take from a potentially limited population, the samples we collected were also used in related genetic and morphological analyses aimed at quantifying the status of Grotto Sculpin (Adams et al. 2013, Day et al. in press). All samples were collected prior to phylogenetic analysis and species description, which preceded listing under the Endangered Species Act in 2013 (USFWS 2013). Sampling was primarily limited by accessible passage and inconsistent fish presence. In small caves (typically less than $500 \mathrm{~m}$ accessible) with limited or rare fish occurrence, we did not sample exhaustively and removed fish haphazardly throughout the accessible length of the cave. In Mystery Cave, where over $3 \mathrm{~km}$ were sampled as part of a larger mark-recapture study, samples were collected haphazardly throughout the length of the sampling area.

In the laboratory, blunt-tipped scissors were used to carefully cut the ventral body wall from the pelvic girdle to the anus in a manner that would not damage the intestine. The entire digestive tract, from the esophagus to the anus, was removed using forceps from all 229 sculpin. Tracts were flushed with distilled water and examined for intestinal parasites using a binocular dissecting scope at 10-40× magnifications. When present, acanthocephalans were enumerated and suspended in $70 \%$ ethanol for fixation and storage at the University of Central Arkansas. Several acanthocephalan specimens with exposed proboscises were isolated from frozen sculpin, cleared, mounted, and morphologically identified as Leptorhynchoides thecatus based on proboscis structure (D. Gettinger, pers. obs.).

\section{Parasites}

Parasitism prevalence was used to descriptively show presence-absence data for Grotto Sculpin populations and allowed us to compare infections rates between our populations (Bush et al. 1997). Prevalence, mean intensity of infection, and mean abundance were calculated for each of our included sculpin populations (Table 1). Prevalence was defined as the number of host individuals infected with at least one acanthocephalan divided by the total number of individuals examined (Bush et al. 1997, Margolis et al. 1982). Mean intensity of infection was calculated as the average number of parasites found among infected Grotto Sculpin (Bush et al. 1997, Margolis et al. 1982, Rozsa et al. 2000). Comparing mean intensities between our populations would indicate whether a difference in the concentration of parasites among parasitized populations was present. Finally, mean abundance is equal to the average number of parasites found among all Grotto Sculpin sampled at a sample site regardless of infection status (Bush et al. 1997, Margolis et al. 1982, Rozsa et al. 2000). 


\section{Results}

\section{Cave versus non-cave}

We examined a total of 229 adult sculpin ranging from $64.5 \mathrm{~mm}$ to $76.5 \mathrm{~mm} \mathrm{SL}$ from six caves, one resurgence, and three surface streams (Table 1). For cave versus surface comparisons, caves were defined as completely subterranean streams requiring penetration to sample, and surface streams, which are only accessible from the surface. For the longest cave sampled, Mystery Cave, samples were collected within the first accessible $3 \mathrm{~km}$ of passage. All other caves were sampled haphazardly as fish were encountered. Precise resurgence distances and cave connectivity are lacking, but see Moss (2013) for Perry County recharge delineations. Eighty-six sculpin were captured from non-cave streams (68 surface, 18 resurgence) and 143 were captured from subterranean cave streams. One-hundred and twenty-seven fish (55\%) were infested with a total of 1628 acanthocephalans. Acanthocephalan distribution within host tissues was restricted to the intestine in 52\% of infected fish and the stomach in 5\%. However, $40 \%$ of all infected fish showed infection across multiple gut tissues. All three measures of parasitism were significantly higher (prevalence $\mathrm{p}=0.001$, intensity $\mathrm{p}=0.01$, and abundance $\mathrm{p}=0.01$, respectively) in cave versus non-cave samples (Table 2 ). Overall acanthocephalan parasitism prevalence across all streams ranged from 0 to $91 \%$ and was significantly higher in cave versus surface streams $(\mathrm{p}<0.001)$. Infection intensity ranged from 0 to 38 worms per infected host, with a mean intensity of 10 (std. dev. 3) acanthocephalans per parasitized fish. Mean intensity of infection and parasite abundances were also significantly different between cave and surface specimens $(\mathrm{p}=0.05$ and $\mathrm{p}=0.01$, respectively).

\section{Specific locations}

Sculpin were found to be parasitized by L. thecatus at all sampling sites except one (Big Creek; Table 1). Mean intensity tended to be similar for sculpin at all sites with the exception of Hot Caverns and Mystery Cave where mean intensity rates were much higher than at other sites (Table 1; Figure 2). Mean parasite abundance was significantly different among cave and non-cave locations and showed a similar pattern to mean intensity where all sites were similar except for much higher intensity rates at Hot Caverns and Mystery Cave ( $\mathrm{p}=0.01)$.

Table 2. Comparison of sculpin parasitism in samples from cave and surface streams in Perry County, Missouri.

\begin{tabular}{c|c|c|c|c|c|c}
\hline Habitat & N & N Parasitized & N Worms & Prevalence & Intensity & Abundance \\
\hline Cave & 143 & 107 & 1562 & $75 \%$ & 15 & 11 \\
\hline Non-cave & 86 & 20 & 66 & $23 \%$ & 3 & 1 \\
\hline
\end{tabular}




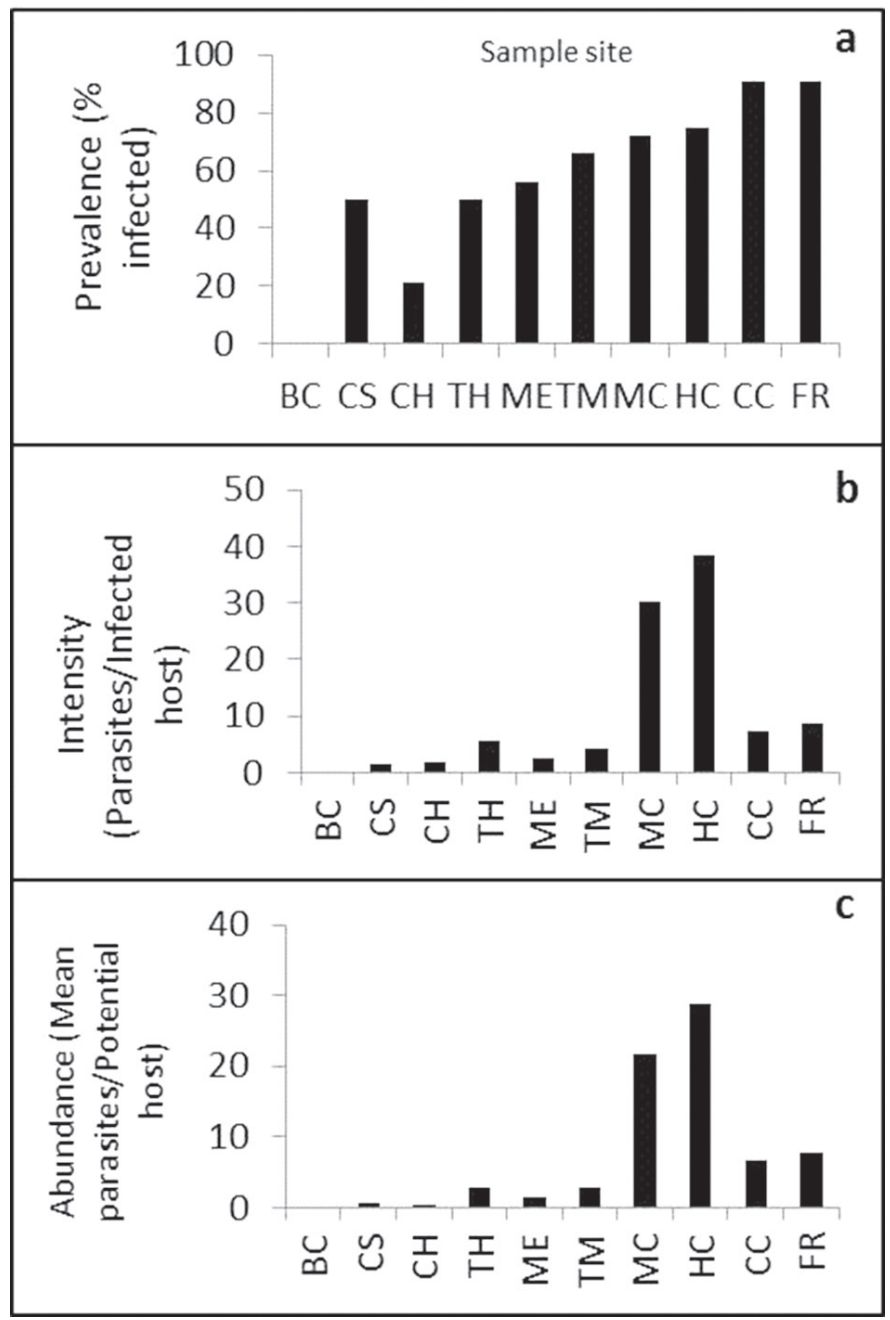

Figure 2. Site specific prevalence (a), intensity (b), and abundance (c) of parasites found in grotto sculpin. Sample site abbreviations correspond with Table 1.

\section{Discussion}

Our observation of what appears to be a successful invasion of the cave environment by acanthocephalans marks the first report of parasitism in a cave-dwelling sculpin and the most inclusive of all cavefish species. Our results revealed that parasitism by Leptorhynchoides thecatus was significantly higher in caves than non-cave stream populations of Grotto Sculpin. While small sample sizes precluded fine-scale resolution of host-parasite population dynamics in individual caves, our data were sufficient to provide an overview of possible explanations for this unique phenomenon that encompass multiple schools of ecological and evolutionary thought. Here we briefly explore the biological relationships of cannibalism and parasitism, complemented by an account 
of how their ecological effects may be compounded and magnified by the perils of subterranean life within the context of conservation.

Subterranean systems have traditionally been thought of as simple, unchanging ecosystems that persist in near or total isolation from surface resources, but this assumption has been the subject of much scrutiny and reconsideration in recent years as studies of nutrient contributions and trophic ecology increase (Huntsman et al. 2011, Schneider et al. 2011, Venarsky et al. 2012). Taxonomic diversity in these harsh environments continues to be revealed (Niemiller and Zigler 2013), as do concerns for their timely descriptions and the implementation of conservation measures (Niemiller et al. 2013).

The cave system inhabited by Grotto Sculpin, is remarkably interconnected and influenced by surface activities and supports the notion of increased complexity. Just as organic matter beneficial to troglobites may enter caves relatively quickly in shallow karst regions, so too can potential contaminants from surface land use practices. Fox et al. (2010) found that Perry County caves were subject to increased levels of urban and agricultural runoff, and sinkholes remain one of the greatest potential threats to Grotto Sculpin. Pesticides, herbicides, metals, and organic waste known to be detrimental to vertebrate physiology that leak into subterranean streams via sinkholes are all likely to have negative impacts on Grotto Sculpin populations, including increasing susceptibility to parasite infection due to reduced condition or health (Khan 2004, Marchand et al. 2012, Kleinertz and Palm 2013). Strengthening these concerns for Grotto Sculpin in particular are new recharge delineation data and vulnerability analyses that suggest overflow between cave systems occurs with some degree of regularity and severity in these systems (Moss 2013).

Point- and nonpoint-source pollution events pose notable threats to Grotto Sculpin populations and could increase susceptibility to parasitism as a result of reduced health condition. Mystery Cave supports the largest documented population of Grotto Sculpin, with estimates ranging from 262 to 509 individuals (Day et al. 2009). This cave has experienced at least one recent mass extirpation event from a point-source pollution event in 2005 when a cow carcass was washed into the cave stream and dissolved oxygen levels dropped below critical levels for fish survival. Burr et al. (2001) also reported a mass extirpation event in Running Bull Cave, the origin of which remains unknown but is suspected to be anthropogenic in nature. Although population abundances in both of these caves appear to be high at present, these data do provide support for continued investigation of fish health and condition in relation to water quality and available food resources.

In these unique karst systems, extensive movement of groundwater serves not only as a means of nutrient transport and fish translocation, but also as means of increasing parasite dispersal and both nutrient and pollution transport. Mertz Cave, which had the lowest incidence of parasitism for a cave, has the largest and most accessible inflowing entrance relative to the other caves tested, which may allow for a higher influx of nutrients from the surface. This may result in less cannibalism and therefore less parasitism (Table 1). In remote or isolated regions of this cave system, a lower influx of surface energy could offer a narrow range of possible hosts for parasites. Therefore, Leptorhynchoides thecatus could be more likely to parasitize Grotto Sculpin in stream 
reaches located in far proximity to allochthonous organic input. Coupled with cannibalism, this may also contribute to the elevated rates of parasitism we observed.

Cannibalism is theorized to promote parasitism (Hatcher et al. 2008), and when considered in conjunction with environmental variability may increase as a function of food scarcity. Amphipods are widely recognized as a common paratenic or intermediate host for acanthocephalans, and represent the primary prey item available to Grotto Sculpin (Gerken, unpublished data). Seasonal or condition-dependent abundance and diversity of available prey items in this system could lead to diet constriction and increased the reliance of Grotto Sculpin on cannibalism, and thus likelihood of parasite infection. Further investigation of trophic dynamics and food web structure in Perry County caves is necessary to test this hypothesis.

\section{Conclusion}

In addition to providing insight on the ecology of Grotto Sculpin and their acanthocephalan parasites, the results of this work elucidate novel data gaps on parasite ecology and their persistence in cave fauna. The results of this study suggest that researchers and managers should take care to investigate the potential influences of parasitism and variation in surface contributions to cave biodiversity population dynamics. Directed studies of the prevalence and epidemiological implications of fish health and parasite infections in cave species are still limited in scope and in need of further inquiry. Future research should seek to understand the population dynamics of parasites in subterranean systems and their impacts on ecosystem ecology and function.

\section{Acknowledgements}

Support for this project was provided by Sigma Xi grant to JL Day at University of Central Arkansas, Missouri Department of Conservation, and U.S. Fish and Wildlife Service. The diligence and dedication of B Pobst of MDC made this project both possible and successful. We are grateful to the Perry County MDC office for use of their facilities, numerous landowners who allowed access to sites, and P Moss of Ozark Underground Laboratory for his unending guidance. We thank G Adams, C Johnson, $S$ Vestal, and K McCabe of UCA. We are immensely grateful to the reviewer of this manuscript for constructive and invaluable input.

\section{References}

Adams G, Burr BM, Day JL, Starkey DE (2013) Cottus specus, a new troglomorphic species of sculpin (Cottidae) from southeastern Missouri. Zootaxa 3609 (5): 484-494. doi: 10.11646/zootaxa.3609.5.4 
Aley TJ, Aley C (1979) Prevention of adverse impacts on endangered, threatened, and rare animal species in Benton and Washington Counties, Arkansas. Northwest Arkansas Regional Planning Commission, Springdale, AR. 35pp.

Biek R, Drummond AJ, Poss M (2006) A virus reveals population structure and recent demographic history of its carnivore host. Science 311: 538-541. doi: 10.1126/science.1121360

Blakeslee AMH, Byers JE, Lesser MP (2008) Solving cryptogenic histories using host and parasite molecular genetics: The resolution of Littorina littorea's North American origin. Molecular Ecology 17: 3684-3696. doi: 10.1111/j.1365-294X.2008.03865.x

Burr BM, Adams GL, Krecja JK, Paul RJ, Warren ML (2001) Troglomorphic sculpins of the Cottus carolinae species group in Perry County, Missouri: Distribution, external morphology, and conservation status. Environmental Biology of Fishes 62: 279-296. doi: 10.1023/A:1011819922403

Bush AO, Lafferty KD, Lotz JM, Shostak AW (1997) Parasitology meets ecology on its own terms: Margolis et al. revisited. Journal of Parastiology 83: 575-583. doi: 10.2307/3284227

Criscione CD, Blouin MS (2007) Parasite phylogeographical congruence with salmon host evolutionary significant units: Implications for salmon conservation. Molecular Ecology 16: 993-1005. doi: 10.1111/j.1365-294X.2006.03220.x

Day JL, Gerken JE, Adams GL (2009) Dynamic population ecology of grotto sculpin, Cottus carolinae, in Perry County, Missouri. Final Report. Cape Girardeau, MO; Missouri Department of Conservation and U.S. Fish and Wildlife Service. 29pp.

Day JL, Starkey DE, Adams G, Brummett S, Keeney D (in press) Population genetics of grotto sculpin (Cottus specus), a new cave-adapted fish species. Environmental Biology of Fishes.

Dick CW, Patterson BD (2007) Against all odds: Explaining high host specificity in dispersalprone parasites. International Journal of Parasitology 37: 871-876. doi: 10.1016/j.ijpara.2007.02.004

Fenolio DB, McAllister CT, Niemiller ML, Soares D, Cooley J (2013) An extreme case of a trematode infection of a larval Ozark Blind Salamander, Eurycea spelaea (Caudata: Plethodontidae) from the Ozark Highlands of Missouri, USA. Speleobiology Notes 5: 34-37.

Fox TJ, Adams GL, Steelman K, Sharum M (2010) Passive sampling of bioavailable organic chemicals in Perry County, Missouri cave streams. Environ Sci Technol 44: 8835-8841. doi: 10.1021/es1019367

Hatcher MJ, Dick JTA, Dunn AM (2008) A keystone effect for parasites in intraguild predation? Biology Letters 4 (5): 534-537. doi: 10.1098/rsbl.2008.0178

Hendrickson DA, Krejca JK, Martinez JMR (2001) Mexican blindcats genus Prietella (Siluriformes: Ictaluridae): An overview of recent explorations. Environmental Biology of Fishes 62 (1-3): 315-337. doi: 10.1023/A:1011808805094

Huntsman BM, Venarsky MP, Benstead JP, Huryn AD (2011) Effects of organic matter availability on the life history of production of a top vertebrate predator (Plethodontidae: Gyrinophilus palleucus) in two caves. Freshwater Biology 56: 1746-1760. doi: 10.1111/j.1365-2427.2011.02609.x

Kennedy CR (2006) Ecology of the Acanthocephala. Cambridge University Press, New York, NY, 260 pp. doi: 10.1017/CBO9780511541902 
Khan RA (2004) Parasites of fish as biomarkers of environmental degradation: A field study. Bulletin of Environmental Contaminants and Toxicology 72: 394-400. doi: 10.1007/ s00128-003-9092-6

Kleinertz S, Palm HW (2013) Parasites of the grouper fish Epinephelus coioides (Serranidae) as potential environmental indicators in Indonesian coastal ecosystems. Journal of Helminthology: 1-14. doi: 10.1017/S0022149X1300062X

Kurta A, Whitaker JO, Wrenn WJ, Soto-Centeno JA (2007) Ectoparasitic assemblages on mormoopid bats (Chiroptera: Mormoopidae) from Puerto Rico. Journal of Medical Entomology 44 (6): 953-958. doi: 10.1603/0022-2585(2007)44[953:EAOMBC]2.0.CO;2

Lamping D, Laws J (2005) Missouri announces 6,000 caves. NSS News 63 (8): 20.

Marchand MJ, van Dyk JC, Barnhoorn IEJ, Wagenaar GM (2012) Histopathological changes in two potential indicator fish species from a hyper-eutrophic freshwater ecosystem in South Africa: a baseline study. African Journal of Aquatic Science 37(1): 39-48. doi: $10.2989 / 16085914.2011 .636902$

Margolis L, Esch GW, Holmes JC, Kuris AM, Shad GA (1982) The use of ecological terms in parasitology (report of an ad hoc committee of the American Society of Parasitologists). Journal of Parasitology 68: 131-133. doi: 10.2307/3281335

McAllister CT, Bursey CR, Trauth SE, Fenolio DB (2006) Helminth parasites of the grotto salamander, Eurycea spelaea (Caudata: Plethodontidae), from Northern Arkansas and Southern Missouri, USA. Comparative Parasitology 73 (2): 291-297. doi: 10.1654/4196.1

McAllister CT, Bursey CR, Fenolio D, Niemiller M (2013) Bothriocephalus sp. (Cestoidea: Bothriocephalidae) from the Georgia blind salamander, Eurycea wallacei (Caudata: Plethodontidae), in Georgia, U.S.A.: First definitive report of a parasite from this host. Comparative Parasitology 80 (2): 308-311. doi: 10.1654/4615.1

McCoy KD, Boulinier T, Tirard T (2005) Comparative host-parasite population structures: disentangling prospecting and dispersal in the black-legged kittiwake Rissa tridactyla. Molecular Ecology 14: 2825-2838. doi: 10.1111/j.1365-294X.2005.02631.x

Moss P (2013) Recharge area delineations and hazard and vulnerability mapping in Perry County, Missouri. Carbonates and Evaporites 28 (1-2): 175-182. doi: 10.1007/s13146-013-0129-6 Muzzall PM, Bowen CA (2002) Parasites of the slimy sculpin, Cottus cognatus Richardson, 1836, from Lake Huron, U.S.A. Comparative Parasitology 69: 196-201. doi: 10.1654/1525-2647(2002)069[0196:POTSSC]2.0.CO;2

Nieberding CM (2005) Comparative phylogeography of the woodmouse Apodemus sylvaticus and of its parasite Heligmosomoides polygyrus in the western Palearctic region: the use of a parasite to get insight in its host evolutionary history. PhD Thesis, Leige, Belgium: University of Liege.

Niemiller ML, Poulson TL (2010) Studies of the Amblyopsidae: past, present, and future. In:

Trajano E, Bichuette ME, Kapoor BG (Eds) The Biology of Subterranean Fishes. Science Publishers, Enfield, NH, 169-280.

Niemiller ML, Graening GO, Fenolio DB, Godwin JC, Cooley JR, Pearson WD, Fitzpatrick BM, Near TJ (2013) Doomed before they are described? The need for conservation assessments of crypic species complexes using an amblyopsid cavefish (Amblyopsidae: Typhlichthys) as a case study. Biodiversity Conservation 22: 1799-1820. doi: 10.1007/s10531-013-0514-4 
Niemiller ML, Zigler KS (2013) Patterns of cave biodiversity and endemism in the Appalachians and interior plateau of Tennessee, USA. PloS ONE 8 (5): e64177. doi: 10.1371/ journal.pone.0064177

Poissant JA, Broders HG (2008) Ectoparasite prevalence in Myotis lucifugus and M. septentrionalis (Chiroptera: Vespertilionidae) during fall migration at Hayes Cave, Nova Scotia. Northeastern Naturalist 5 (4): 515-522. doi: 10.1656/1092-6194-15.4.515

Poulson TL (1963) Cave adaptation in amblyopsid fishes. The American Midland Naturalist 70: 257-290. doi: 10.2307/2423056

Poulson TL, Lavoie KH (2000) The trophic basis of subsurface ecosystems. In: Wilkens H, Culver DC, Humphreys WF (Eds) Ecosystems of the World 30: Subterranean Ecosystems. Elsevier, Amsterdam, 231-249.

Rozsa L, Reiczigel J, Majoros G (2000) Quantifying parasites in samples of hosts. Journal of Parasitology 86 (2): 228-232.

Santamaria S, Faille A (2007) Rhachomyces (Ascomycota, Laboulbeniales) parasites on caveinhabiting Carabid beetles from the Pyrenees). Nova Hedwigia 85 (1-2): 159-186. doi: $10.1127 / 0029-5035 / 2007 / 0085-0159$

Schneider K, Christman MC, Fagan WF (2011) The influence of resource subsidies on cave invertebrates: results from an ecosystem-level manipulation experiment. Ecology 92 (3): 765-776. doi: 10.1890/10-0157.1

Seneviratne SS, Fernando HC, Udagama-Randeniya PV (2009) Host specificity in bat ectoparasites: A natural experiment. International Journal for Parasitology 39: 995-1002. doi: 10.1016/j.ijpara.2008.12.009

Trajano E (2001) Ecology of subterranean fishes: An overview. Environmental Biology of Fishes 62: 133-160. doi: 10.1023/A:1011841913569

U.S. Fish and Wildlife Service (2013) Endangered and threatened wildlife and plants: Determination of endangered species status for the grotto sculpin (Cottus specus) throughout its range. Federal Register 78 (186): 58938-58955.

Vandike JE (1985) Movement of shallow groundwater in the Perryville Karst area, southeastern Missouri: Missouri Department of Natural Resources' Division of Geology and Land Survey, Water Resources Report No 40.56 pp.

Venarsky MP, Benstead JP, Huryn AD (2012) Effects of organic matter and season on leaf litter colonization and breakdown in cave streams. Freshwater Biology 57: 773-786. doi: 10.1111/j.1365-2427.2012.02742.x

Whiteman NK, Parker PG (2005) Using parasites to infer host population history: A new rationale for parasite conservation. Animal Conservation 8: 175-181. doi: 10.1017/ S1367943005001915

Whiteman NK, Kimball RT, Parker PG (2007) Co-phylogeography and comparative population genetics of the threatened Galapagos hawk and three ectoparasite species: Ecology shapes population histories within parasite communities. Molecular Ecology 16: 47594773. doi: 10.1111/j.1365-294X.2007.03512.x

Wirth T, Meye A, Achtman M (2005) Deciphering host migrations and origins by means of their microbes. Molecular Ecology 14: 3289-3306. doi: 10.1111/j.1365-294X.2005.02687.x Zar JH (1999) Biostatistical Analysis, $4^{\text {th }}$ edition. Prentice Hall, Upper Saddle River, NJ. 